\title{
New records of the enigmatic species - Ronbuberia eurytarsipennis (W. Horn, 1905) (Coleoptera: Cicindelidae)
}

\author{
Новые находки таинственного вида - Ronbuberia eurytarsipennis \\ (W. Horn, 1905) (Coleoptera: Cicindelidae)
}

\author{
Andrey V. Matalin ${ }^{1,2}$, Jiří Moravec $^{3}$ \\ A.В. Маталин ${ }^{1,2}$, Йиржи Моравеч ${ }^{3}$
}

\footnotetext{
Moscow State Pedagogical University, Education-Scientific Centre of Ecology \& Biodiversity, Kibalchicha str. 6, build. 3, 129164 Moscow, Russia. E-mail: andrei-matalin@yandex.ru

${ }^{1}$ Московский педагогический государственный университет, Учебно-научный центр экологии и биоразнообразия, ул. Кибальчича д. 6, корп. 3, 129164 Москва, Россия.

${ }^{2}$ Pirogov Russian National Research Medical University, Pediatric Faculty, Department of Biology, Ostrovitianova str. 1, 117997 Moscow, Russia.

${ }^{2}$ Российский национальный исследовательский медицинский университет им. Н.И. Пирогова, педиатрический факультет, кафедра биологии, ул. Островитянова д. 1, Москва 117997, Россия.

${ }_{3}^{3}$ Sadová 336/21, 67904 Adamov 1, Czech Republic. E-mail: jirmor@quick.cz
}

KEY WORDS. Coleoptera, Cicindelidae, Odontocheilina, tiger beetles, Ronhuberia, R. eurytarsipennis, new records, Oxapampa, Peru.

КЛЮЧЕВЫЕ СЛОВА. Coleoptera, Cicindelidae, Odontocheilina, жуки скакуны, Ronhuberia, R. eurytarsipennis, новые находки, Охапампа, Перу.

ABSTRACT. Ronhuberia eurytarsipennis (W. Horn, 1905) from the subtribe Odontocheilina W. Horn, 1899 sensu Moravec [2012] known only by the two types from Ukayali (Peru) has been found recently in the Peruvian province Oxapampa. Additional data, measurements and illustrations of diagnostic characters of the newly collected specimens, as well as of the type specimens, are presented.

PЕЗЮМЕ. Ronhuberia eurytarsipennis (W. Horn, 1905) из подтрибы Odontocheilina W. Horn, 1899 sensu Moravec [2012], известный только по двум типам из Укаяли (Перу), найден в перуанской провинции Оксапампа. Представлены линейные размеры и иллюстрации важнейших морфологических признаков вновь найденных особей и типовых экземпляров.

\section{Introduction}

There are several cases within Cicindelidae when a new species was described according to the study of a sole or unit (only two) specimens, particularly by historical authors, such as Walther Horn. Sometimes, new exemplars of such species are subsequently collected in the nature or are found in the museum collections. However, a number of species remains known only from the type specimens. Ronhuberia eurytarsipennis (W. Horn, 1905), based on Odontochila eurytarsipennis W. Horn, 1905, described from two syntypes (male and female) from the Peruvian region of Ucayali, is a good example. During next 115 years after its description [Horn, 1905] and illustration [Horn, 1910] this species was not found in nature or in the museum collections [Mandl, 1951; Moravec, Kudrna, 2002; Erwin, Pearson, 2008]. Its previous records from Ecuador by Pearson et al. [1999] and by Cassola, Pearson [2001] (as Pentacomia eurytarsipennis) was based on a misidentification, as they recorded in fact a different species which was described later as Pentacomia (Pentacomia) fernandezi Cassola, 2000 from Colombia and was subsequently recorded from Ecuador [Cassola, Onore, 2002; Moravec, Kudrna, 2002].

In October 2017 three specimens of $R$. eurytarsipennis were rediscovered in the Peruvian province Oxapampa. The additional data on their morphological features and measurements are given and discussed below.

\section{Material and methods}

The recently collected specimens are kept in the collection of Moscow State Pedagogical University, Moscow, Russia (MPU). The type specimens are de-

How to cite this article: Matalin A.V., Moravec J. 2020. New records of the enigmatic species - Ronhuberia eurytarsipennis (W. Horn, 1905) (Coleoptera: Cicindelidae) // Russian Entomol. J. Vol.29. No.1. P.33-37. doi: 10.15298/rusentj.29.1.05 
posited in the Senckenberg Deutsches Entomologisches Institut, Müncheberg, Germany (SDEI).

Measurements were made with an ocular-micrometer on the stereoscopic microscope Leica M165c (Carl Zeiss) as follows: TL — total body length without labrum (from anterior margin of clypeus to the apex of elytra along the suture), HW - width of head with the eyes (in the widest place), LL - length of labrum with apical teeth (along the midline), LW - width of labrum (in the widest place), PL - length of pronotum (along the midline), PW - width of pronotum (in the widest place), EL length of elytra with apical spine (from the base of scutellum along the suture), EW - width of elytra (in the widest place), SL — length of sutural spine, AL length of aedeagus (from the base to the apex).

The photographs of habitus and details of the recently collected specimens (Figs 1-9) were taken by the first author with a Canon EOS 40D camera with a MP-E 65 $\mathrm{mm}$ macro lens. Aedeagus photos were taken with Canon EOS 6D camera attached to a Carl Zeiss AXIO Scope.A1 microscope. All photos were processed using
Zerene Stacker software. The photographs of the two type specimens (Figs 10-20) were taken by the second author with a Nikon Coolpix 990 digital camera through a MBS-10 stereo microscope. For preparing the slides the aedeagi were consistently stand in $10 \% \mathrm{KOH}(24$ h.), 4\% acetic acid (5 min.) and washed with cold distilled water ( 5 min.), and then were preserved with Euparal $(\mathrm{D} \sim 1.05)$ media.

\section{Ronhuberia eurytarsipennis (W. Horn, 1905)}

Figs 1-20.

Odontochila eurytarsipennis W. Horn, 1905: 148 (type locality — Ucayali, Peru; see below).

Pentacomia (Pentacomia)? eurytarsipennis: Wiesner 1992: 83. Ronhuberia eurytarsipennis: Moravec, Kudrna, 2000: 32-33 (Fig. 2b), 24 (Fig. 3), 26 (Figs 15-19).

non Pentacomia eurytarsipennis sensu Pearson et al., 1999 [nec Cassola, Pearson, 2001], which is Ronhuberia fernandezi (Cassola, 2000).

TYPE MATERIAL. Lectotype $\sigma^{7}$ and paralectotype 9 of Odontochila eurytarsipennis W. Horn, 1905 designated by Moravec [2020] (both SDEI) - come from Peruvian Amazonia, a long way from the localities of the newly collected adults, providing that the

Table 1. The color and morphological features of the specimens of $R$. eurytarsipennis. Таблица 1. Особенности строения и окраски особей $R$. eurytarsipennis.

\begin{tabular}{|c|c|c|}
\hline Features & $\begin{array}{c}\text { Type specimens } \\
\text { (old, partly faded or tarnished) }\end{array}$ & Newly recorded specimens \\
\hline Genae & metallic black with feeble green lustre & $\begin{array}{l}\text { metallic black with feeble green or bluish-green } \\
\text { lustre }\end{array}$ \\
\hline Clypeus & metallic green with purple reflection & $\begin{array}{l}\text { metallic golden-green with cupreous reflection and } \\
\text { light purple tinge in one female }\end{array}$ \\
\hline Labrum & $\begin{array}{l}\text { metallic green with black-purple basal } \\
\text { and anterior margin in male and metallic } \\
\text { black with purple and green reflection in } \\
\text { female; with two pairs of setae }\end{array}$ & $\begin{array}{l}\text { metallic black with green anterior two-thirds and } \\
\text { blue luster along inner sides of basal impressions } \\
\text { in male and first female, but with bright golden- } \\
\text { green anterior two-thirds, purple lateral margins } \\
\text { and light blue tinge along inner sides of basal } \\
\text { impressions in second female; apical teeth and } \\
\text { apices of lateral tooth brown in females; with three } \\
\text { pairs of setae (anterior pair is double) in male and } \\
\text { two pairs of setae in females }\end{array}$ \\
\hline Scape & metallic-black with bright green lustre & $\begin{array}{l}\text { metallic-black with bright blue luster in basal } \\
\text { third, golden-green reflection in apical two-thirds } \\
\text { and purple-tinged apex }\end{array}$ \\
\hline $\begin{array}{l}\text { Antennomeres } \\
2^{\text {nd }}-4^{\text {th }}\end{array}$ & $\begin{array}{l}\text { metallic purple-violaceous with bronze- } \\
\text { green iridescence }\end{array}$ & $\begin{array}{l}\text { metallic bluish-violaceus or purple-violaceous } \\
\text { with purple or golden-green iridescence in apical } \\
\text { third }\end{array}$ \\
\hline Pronotum & $\begin{array}{l}\text { metallic olivaceous-green with bronze } \\
\text { lustre in male and bronze-cupreous } \\
\text { lustre in female }\end{array}$ & $\begin{array}{l}\text { metallic olivaceous-green with bronze or bronze- } \\
\text { cupreous lustre in both sexes; in female anterior } \\
\text { margin sometimes with bright rainbow luster }\end{array}$ \\
\hline Mesepisterna & metallic black & $\begin{array}{l}\text { metallic black with purple-bronze or purple-gold } \\
\text { reflection in females and purple-golden-green } \\
\text { reflection in male }\end{array}$ \\
\hline Elytra & $\begin{array}{l}\text { sublateral anterior area and posterior } \\
\text { declivity iridescent-green in male and } \\
\text { golden-bronze to cupreous in female }\end{array}$ & $\begin{array}{l}\text { sublateral anterior area and posterior declivity } \\
\text { iridescent- golden-bronze to cupreous in both } \\
\text { sexes }\end{array}$ \\
\hline Coxae & metallic black-brown & $\begin{array}{l}\text { metallic black-brown; fore with bluish-green, } \\
\text { middle and hind with golden-green reflection }\end{array}$ \\
\hline Trochanters & ochre-brown & fore and middle ochre-brown, hind dark-brown \\
\hline
\end{tabular}



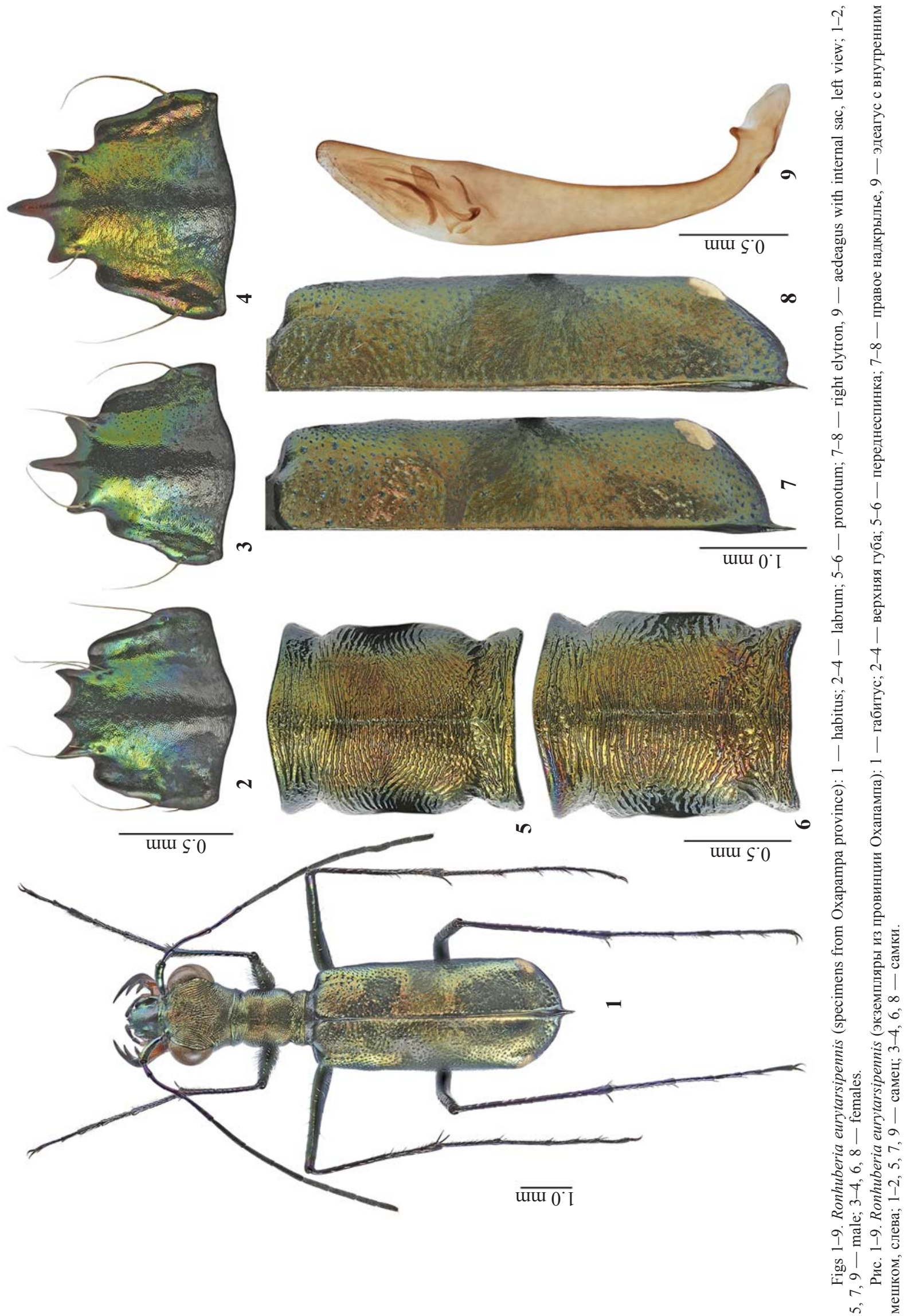


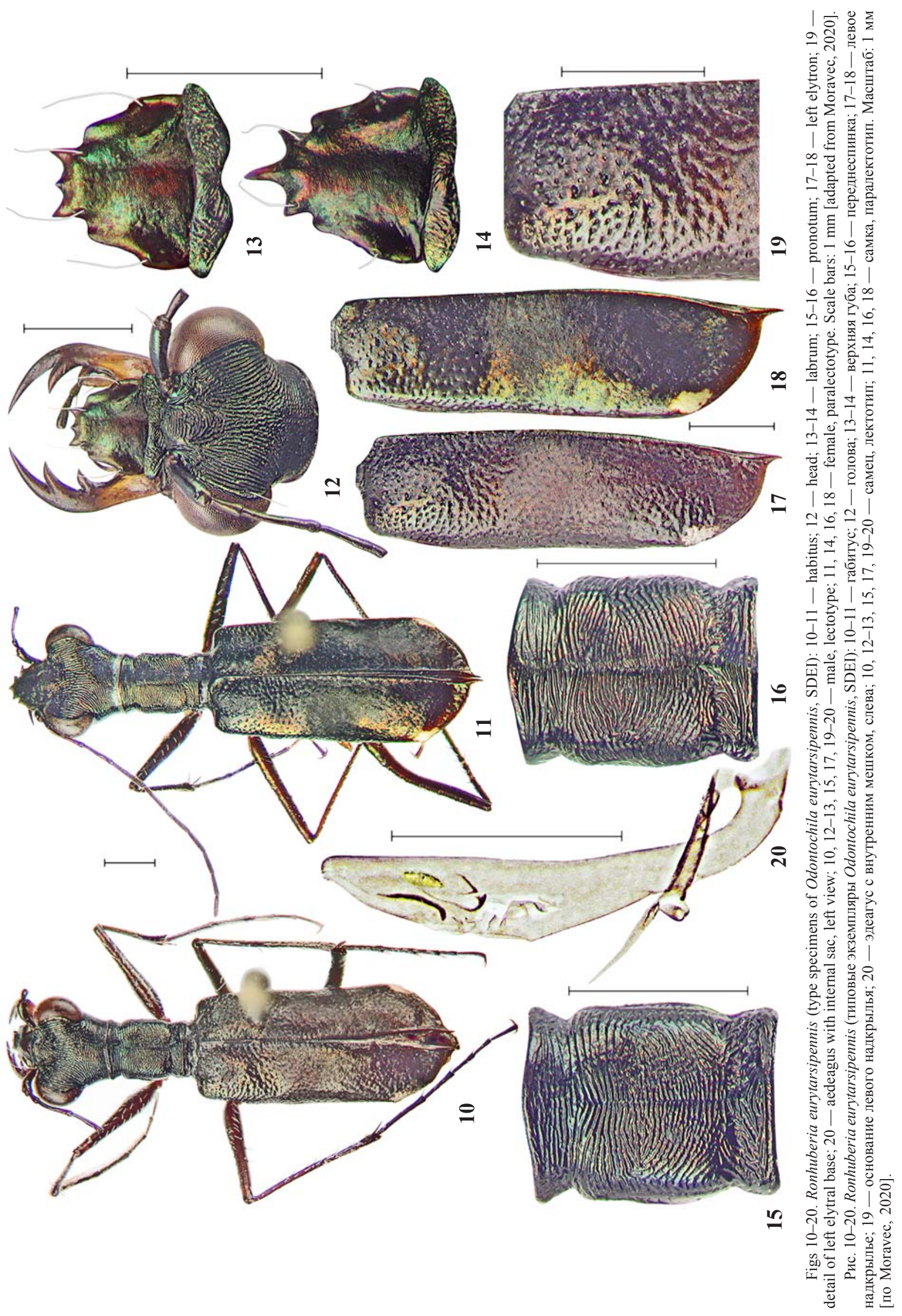


type locality name "Ucayali, Peru" stated by HoRn [1905] and added in writing by hand on the printed label "Staudinger", is correct [Moravec, 2020].

ADDITIONAL MATERIAL: $1 \uparrow$ - Peru, Pasco Department, Oxapampa Province, Pozuzo District, $5 \mathrm{~km} \mathrm{~S} \mathrm{Santa} \mathrm{Rosa} \mathrm{vill.,} \mathrm{h}$ $1560 \mathrm{~m}, 10^{\circ} 00^{\prime} 23^{\prime \prime} \mathrm{S} 75^{\circ} 27^{\prime} 36^{\prime \prime} \mathrm{W}, 5-12.10 .2017$, leg. A. Sokolov (MPU); $10^{\top} 1$ 우 - Peru, Pasco Department, Oxapampa Province, Pozuzo District, Santa Rosa vill., h 1600 m, 13-16.10.2017, leg. A. Petrov (MPU).

DIFFERENTIAL DIAGNOSIS. The two known species of Ronhuberia Moravec, Kudrna, 2002 are characterized by their elytral surface which is almost smooth and chatoyantcoloured posteriad of discal impression with widely diffusing, velvety black central zone that may change to iridescent gold-bronze (depending on light-angles). Ronhuberia fernandezi (Cassola, 2000), the type species of the genus, differs in a complex of diagnostic characters [Moravec, Kudrna, 2002; Moravec, 2020], yet immediately in having immaculate elytra and an extremely coarse sculpture on the elytral base and pronotal surface.

New data about some morphological features as (Table) well as the basic measurements of newly recorded specimens of this extremely rare species are presented below. The coloration and measurements of the types are given after Moravec, Kudrna [2002]; it must be noted here that the type specimens are partly tarnished and faded as usual in very old specimens (Figs 10-20).

DIMENSION. With the data on newly collected exemplars the sizes $(\mathrm{mm})$ and proportions of all known specimens of R. eurytarsipennis are as follows (males/females): TL 8.0/7.8-8.5; HW - 2.1-2.15/2.1-2.3; LL - 0.8/0.9-1.05; LW - 0.9/0.9-1.0; LL/LW - 0.89/1.0-1.11; PL - 1.5/ 1.4-1.6; PW - 1.25/1.1-1.25; PL/PW - 1.2-1.3/1.24 1.28; EL - 4.9-5.0/4.8-5.2; EW - 2.2-2.3/2.2-2.4; EL/ $\mathrm{EW}-2.13-2.27 / 2.17-2.18 ; \mathrm{SL}-0.2-0.25 / 0.2-0.25 ; \mathrm{AL}$ - 1.97-2.2.

REMARKS. It is noteworthy that Wiesner [1992] catalogued $R$. eurytarsipennis (with a question mark) in a diagnostically very different genus Pentacomia Rivalier, 1969. Similarly, $R$. fernandezi was originally described by Cassola [2000] as Pentacomia, despite its distinct characters of which he stressed the metallic coloured labrum only. Moravec, Kudrna [2002] thoroughly re-described and additionally illustrated these two species, and for their remarkable diagnostic characters, the authors transferred them to a separate genus Ronhuberia.

It must be noted here that the genus Pentacomia Bates, 1872 diagnostically differs from all other genera of the subtribe Odontocheilina W. Horn, 1899 sensu Moravec [2012], including all genera which were originally described as subgenera of Pentacomia by Rivalier [1969], as demonstrated by Moravec [2018a-b, 2020]. The illustrations of the two type specimens of $R$. eurytarsipennis (Figs 10-20) are the originals taken by the second author of this present paper, also published in Moravec, Kudrna [2002] and Moravec [2020].

Acknowledgements. We are very grateful to Dr. Alexander Petrov and Mr. Alexander Sokolov (both from Moscow,
Russia) who very kindly loaned material for this study. The second author would also like to thank the staff of the SDEI collection for their kind assistance during his visits to the collection and for loans of the type specimen.

\section{References}

Cassola F. 2000. A new Pentacomia from Colombia (Coleoptera: Cicindelidae) // Mitteilungen des Internationalen Entomologischen Vereins, Frankfurt. Vol.25. P.97-102.

Cassola F., Onore G. 2002. Nuevos registros de Escarabajos Tigre para la fauna del Ecuador (Coleoptera, Cicindelidae) // Revista de la Pontifical Universidad Católica del Ecuador. No.69. P.67-77.

Cassola F., Pearson D.L. 2001. Neotropical Tiger Beetles (Coleoptera: Cicindelidae): Checklist and Biogeography // Biota Colombiana. Vol.2. No.1. P.3-24.

Erwin T.L., Pearson D.L. 2008. A Treatise on the Western Hemisphere Caraboidea (Coleoptera) their classification, distribution, and ways of life. Vol. 2. Carabidae - Nebriiformes $2-$ Cicindelitae. Sofia-Moscow: Pensoft. 365 pp. +33 pl.

Horn W. 1905. Die Gattung Oxygonia und Odontochila // Deutsche Entomologische Zeitschrift. Jg.1905. H.1. S.145-149.

Horn W. 1910. Coleoptera Adephaga, fam. Carabidae, subfam. Cicindelinae // Wytsman P. (ed.). Genera Insectorum. Vol.82. P.105-208.

Mandl K. 1951. Cicindelidae (Col.) // Beiträge zur Fauna Perus. Vol.1. P.211-221.

Moravec J., Kudrna A. 2002. Ronhuberia gen. n with type species Pentacomia fernandezi (Cassola) comb. n.; R. eurytarsipennis (W. Horn) comb. n. // Cicindela. Vol.34. Nos3-4. P.17-37.

Moravec J. 2012. Taxonomic and nomenclatorial revision within the Neotropical genera of the Subtribe Odontochilina in a new sense - 1. Some taxonomic changes in Odontocheila (Coleoptera: Cicindelidae) // Acta Musei Moraviae, Scientiae biologicae (Brno). Vol.97. No.2. P.13-33.

Moravec J. 2018a. Taxonomic and nomenclatorial revision within the Neotropical genera of the subtribe Odontocheilina W. Horn in a new sense - 20. Beckerium W. Horn stat. restit., Mesochila Rivalier stat. nov. and Poecilochila Rivalier stat. nov. (Coleoptera: Cicindelidae) // Acta Musei Moraviae, Scientiae biologicae (Brno). Vol.103. No.2. P.127-206.

Moravec J. 2018b. Taxonomic revision of the Neotropical tiger beetle genera of the subtribe Odontocheilina - Volume 1. Odontocheila Laporte de Castelnau, Cenothyla Rivalier and Phyllodroma Lacordaire (Coleoptera: Cicindelidae). Lednice na Moravì: Biosférická rezervace Dolní Morava, o.p.s., Czech Republic. $623+2$ pp.

Moravec J. 2020. Taxonomic Revision of the Neotropical Tiger Beetle Genera of the Subtribe Odontocheilina - Volume 2. Lednice na Moravì: Biosférická rezervace Dolní Morava, o.p.s., Czech Republic (in press).

Pearson D.L., Buestán J., Navarrete R. 1999. The tiger beetles of Ecuador: their identification, distribution and natural historty (Coleoptera: Cicindelidae) // Contributions of Entomology, International. Vol.3. No.2. P.189-315.

Rivalier E. 1969. Démembrement du genre Odontochila (Col., Cicindelidae) et révision des principales espèces // Annales de la Société entomologique de France, Nouvelle serie. Vol.5. No.1. P.195-237.

Wiesner J. 1992. Verzeichnis der Sanlaufkäfer der Welt. Checklist of the Tiger Beetles of the World (Coleoptera, Cicindelidae). Keltern: Erna Bauer Verlag. 364 S. 